\section{PEMBERDAYAAN \\ PEREMPUAN PANTAI BETING DALAM PENGOLAHAN DODOL MANGROVE}

\section{Sri Hapsari Wijayanti*, Francisca Hermawan, Yussi Ramawati}

Fakultas Ekonomi dan Bisnis, Universitas Katolik Atma Jaya, Jakarta

\section{Article history}

Received : 06-03-2018

Revised : 14-05-2018

Accepted : 21-05-2018

\section{*Corresponding author}

Sri Hapsari Wijayanti

Email : sri.hapsari@atmajaya.ac.id

\section{Abstraksi}

Mangrove banyak ditemukan di Pantai Beting, Kecamatan Muaragembong, Bekasi, Jawa Barat. Akan tetapi, belum banyak masyarakat di sana yang memaksimalkan potesi alam mangrove untuk diolah menjadi produk panganan yang bernilai ekonomis. Dengan mengandalkan potensi alam mangrove pidada yang banyak ditemukan, kaum perempuan di Pantai Beting perlu diberdayakan. Karena itu, tujuan kegiatan ini adalah (1) memberikan pelatihan pembuatan dodol mangrove pidada, pengemasan, dan pemasaran bisnis dodol pidada; (2) melakukan evaluasi dan monitoring pascapelatihan. Subjek kegiatan ini adalah 22 perempuan yang tinggal di Pantai Beting. Metode yang digunakan adalah praktik langsung pembuatan dodol oleh narasumber setempat. Selain itu,metode ceramah, diskusi, dan demonstrasi digunakan untuk memberikan pelatihan pengemasan dan pemasaran. Evaluasi dan monitoring disampaikan dengan metode wawancara dan FGD dengan berfokus pada bauran pemasaran, yaitu produk, harga, tempat, dan promosi. Kegiatan ini menghasilkan produk dodol yang berbeda dari sebelumnya. Perbedaan meliputi tingkat kebersihan, bentuk dodol, dan kemasannya. Harga dodol telah mengalami penyesuaian. Adapun tempat pemasaran masih dilakukan sendiri oleh produsen atau melalui kenalan pemilik warung. Promosi bukan hanya dari mulut ke mulut, melainkan sudah sampai ke pemasaran secara daring meskipun melalui perantara.

Kata Kunci: Kemasan, Komunikasi, Mangrove Pidada, Pemasaran, WOM

\begin{abstract}
Mangrove was found in Pantai Beting, Muaragembong sub-district, Bekasi, West Java. However, not many people there maximize the potential of natural mangrove to be processed into a product of economic value. By relying on the abundant potential of mangrove pidada, women in Pantai Beting need to be empowered. Therefore, the purpose of this activity is to provide (1) making of pidada's dodol production, packaging, and marketing of its business; (2) post-training evaluation and monitoring. The subject of this activity is 22 women who live in Pulau Beting. The method used is the practise of making dodol by local facilitator. In addition, we used lecture, discussion, and demonstration methods are used to provide packaging and marketing training. Evaluation and monitoring are delivered by interview and FGD methods by focusing on the marketing mix, ie product, price, place, and promotion. This activity produces different lunkhead products than before. Differences include the level of cleanliness, dodol shape, and its packaging. The price also has been adjusted. The place of marketing is still done by the producer or through the acquaintance of market. Promotion is not just word of mouth (WOM), but has been up to marketing online though intermediaries by someone.
\end{abstract}

Keywords: Communication, Mangrove Pidada, Marketing, Packaging, WOM 


\section{PENDAHULUAN}

Mangrove ditemukan hampir di seluruh kepulauan di Indonesia karena mudah tumbuh dan berkembang di pantai dengan sungai yang besar dan terlindung meskipun juga dapat tumbuh di daerah pesisir (Noor et al., 2006). Di samping itu, mangrove mudah beradaptasi di lingkungan yang ekstrem, seperti kondisi tanah tergenang, kadar garam tinggi dan kurang stabil (Noor et al., 2006).

Dari segi ekonomi, Ifthianty (2014) membagi nilai keuntungan ekonomi ekosistem mangrove di Pantai Baros Kabupaten Bantul Yogyakarta dalam keuntungan langsung (direct benefits), tidak langsung (indirect benefits), opsional (optional benefits), dan keberadaan (excistence benefits). Nilai manfaat ekonomi tidak langsung, seperti pencegahan erosi, peningkatan produksi tanaman (farm), dan pensuplaian pakan ternak, menyumbang nilai tertinggi dalam membuktikan fungsi ekologi kawasan mangrove. Nilai ekonomi ini berhubungan dengan luas area mangrove: makin luas makin bernilai ekonomi (Ifthianty, 2014).

Saat ini keberadaan hutan mangrove makin terdesak oleh kepentingan manusia. Perilaku membabat hutan, misalnya, dapat menyebabkan abrasi, menghilangnya satwa atau biota laut yang hidup dalam hutan mangrove, meningkatkan intrusi air laut ke daratan, serta mengurangi pendapatan nelayan pesisir untuk mencari ikan, kepiting, dan udang. Bahkan, ada anggapan bahwa mangrove menghalangi lajunya perahu ke laut (Wiyono, 2004). Rendahnya pendidikan masyarakat menyebabkan rendahnya pula kesadaran masyarakat dalam peran serta melestarikan mangrove; karena itu, perlu dilakukan pemberdayaan masyarakat guna melestarikan hutan mangrove melalui pendidikan dan pengarahan (Hamid \& Murtini,2013).

Salah satu wilayah pesisir di pinggiran kota Jakarta yang lebat ditumbuhi mangrove adalah Pantai Beting, Desa Pantai Bahagia, Kecamatan Muaragembong, Bekasi. Kecamatan Muaragembong terletak di Pantai Utara Kabupaten Bekasi berhadapan dengan Teluk Jakarta. Untuk mencapai Pantai Beting, pengunjung harus menaiki perahu boat dalam waktu tempuh sekitar dua jam sambil menyusuri Sungai Citarum. Di sepanjang Pantai Beting itulah wisatawan dapat menikmati pemandangan mangrove beserta aneka biota lautnya.

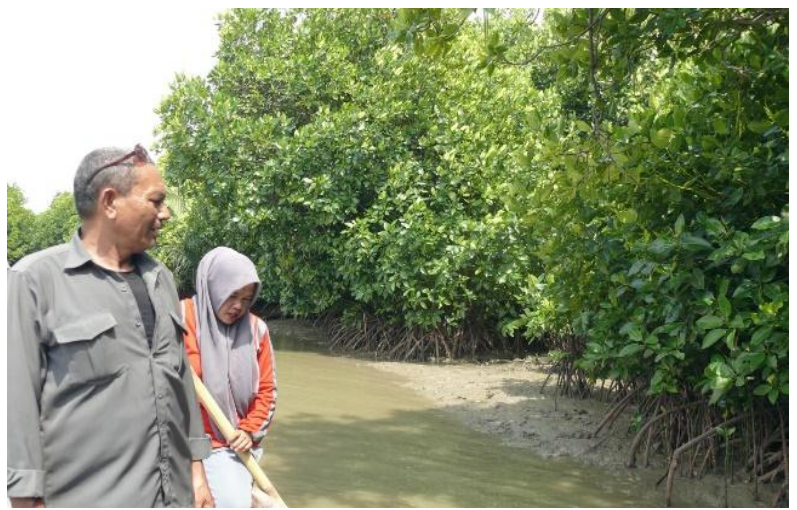

Gambar 1. Menyusuri Sungai Citarum

Jenis mangrove, seperti pidada (Sonneratia spp), api-api (Aviceneernia spp), dan bakau (Rhizophora spp), banyak tumbuh di sekitar Sungai Citarum. Salah satu jenis mangrove yang dapat dimanfaatkan buahnya oleh penduduk di sana adalah pidada. Mangrove pidada tumbuh hingga mencapai tinggi satu meter di sepanjang sungai, bahkan di pinggir-pinggir jalan dan depan rumah penduduk di Pantai Beting. Kayu mangrove pidada dapat digunakan untuk berbagai kebutuhan, maka tak heran jika banyak pohon pidada ditebang untuk memenuhi kebutuhan hidup sehari-hari. Meskipun demikian, jika langka ditemukan, buah pidada masih dapat dicari masyarakat di sepanjang Pantai Bendera (bincang-bincang dengan warga Pantai Beting, 22 Mei 2017).

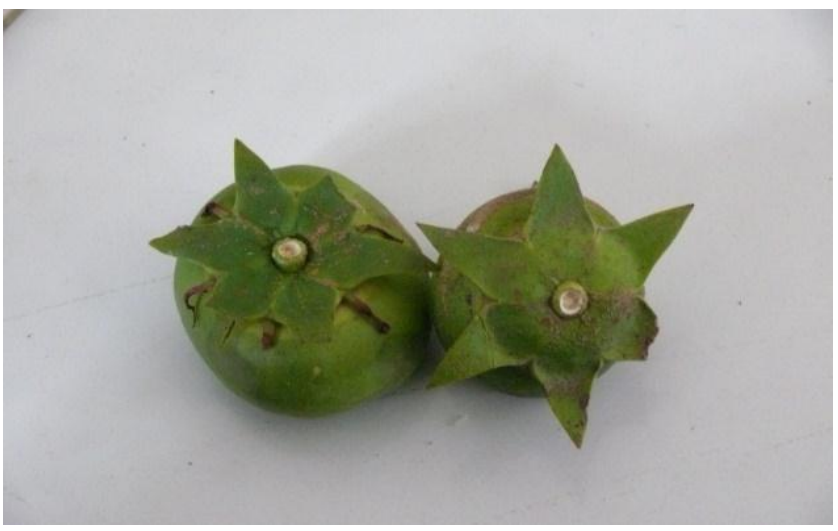

Gambar 2. Buah Mangrove Pidada

Buah pidada berbentuk bulat, ujungnya bertangkai dan dasarnya terbungkus kelopak bunga (Noor et al., 2006). Apabila masa panen, buahnya cukup banyak dan warna buahnya hijau. Buah pidada mengandung vitamin A, B1, B2, dan C sebagai sumber energi dan protein. Mangrove pidada berpotensi bisnis untuk meningkatkan pendapatan keluarga (Sabana, 2014). Daging dan biji buah 
pidada hampir $73 \%$ dapat dimakan (Manalu, Salaman, Retiaty, \& Kurniawati, 2013), dan rasanya khas asam atau manis. Jika pada saat dikupas, daging buah pidada berwarna putih, biasanya pidada berasa asam. Sebaliknya, jika dikupas berwarna merah, pidada berasa manis (bincangbincang dengan salah satu warga, 22 Mei 2017). Buah pidada dapat langsung dimakan begitu saja atau diolah menjadi berbagai panganan, seperti klepon, dodol, krupuk, rempeyek, selai, dan sirup. Informasi promosi yang diberikan pada banyak olahan mangrove umumnya adalah produk olahan tersebut tidak mengandung bahan pengawet, tanpa pewarna, dan mempunyai kandungan gizi yang tinggi. Penjualannya pun saat ini sudah melalui media sosial (Wiediartini, Santiasih, \& Riantini, 2016).

Salah satu produk olahan mangrove pidada adalah dodol. Dodol mangrove merupakan salah satu andalan bagi masyarakat pesisir umumnya, termasuk warga Pantai Beting, Desa Pantai Bahagia. Di Pantai Beting masih banyak ditemukan buah mangrove jenis pidada yang tercecer di sepanjang jalan, di halaman rumah warga, atau di tepi sungai. Di sana belum banyak warga yang memiliki keterampilan mengolah buah mangrove pidada menjadi dodol atau panganan lainnya.

Kaum perempuan di Pulau Beting berpotensi untuk diberdayakan melalui pemanfaatan sumber daya alam sekitar, yaitu mangrove pidada, sehingga dapat membantu ekonomi rumah tangga dan mengentaskan kemiskinan. Dengan kata lain, kaum perempuan dapat turut berperan dalam rumah tangga dengan cara didorong untuk berwirausaha (Kompas, 23 Januari 2017). Salah satu perempuan yang sudah sekitar setahun menggeluti dodol pidada adalah Ibu Maunah. Keahliannya membuat dodol pidada patut ditularkan kepada kaum ibu lainnya yang tinggal di lingkungannya. Selama produksi, karena hanya dibantu oleh suaminya, produksi lbu Maunah tidak banyak.

Dengan alat dan bahan yang terbatas, Ibu Maunah hanya mampu memproduksi dodol maksimal tidak lebih dari $5 \mathrm{~kg}$ per minggu. Dengan dibantu suaminya, ia memasarkan dodolnya dari mulut ke mulut dan menitipkannya di warungwarung. Selain itu, jika diamati dari segi kemasan, dodol pidada masih dikemas sangat sederhana. Label kemasan dibuat dengan menggunakan kertas HVS putih yang dicetak tinta warna hitam dan ditempel di mika bungkus dodol. Juga dodol yang diiris-iris berbentuk persegi panjang lalu dibalut di dalam plastik yang tipis tampak masih tidak sama rata ukurannya. Tidak ada perhitungan berapa bobot dodol yang harus dimasukkan dalam sebungkus mika.

Tujuan kegiatan pengabdian kepada masyarakat ini adalah (1) memberikan pelatihan pembuatan dodol mangrove pidada, pengemasan, dan pemasaran bisnis dodol pidada; (2) melakukan evaluasi dan monitoring pasca pelatihan. Kegiatan ini diharapkan bermanfaat bagi kaum perempuan di Pulau Beting khususnya agar menyadari dan memanfaatkan potensi alam sekitar, melestarikan sumber daya alam mangrove, menambah penghasilan keluarga, menumbuhkan jiwa wirausaha, dan menambah wawasan mengenai pemasaran.

\section{TAHAPAN PELAKSANAAN}

Peserta kegiatan ini adalah 22 perempuan di Pantai Beting, Desa Pantai Bahagia. Kegiatan diselenggarakan pada 6 Mei 2017 di kediaman ibu Siti Hodijah. Metode yang digunakan disesuaikan dengan dua tujuan program.

Pertama, praktik pembuatan dodol pidada didemonstrasikan langsung oleh lbu Maunah. Sebagai fasilitator setempat, ibu Maunah dipilih agar terjadi transfer ilmu dan keterampilan mengolah dodol pidada dari warga untuk warga. Di sini Tim bertindak sebagai pengamat yang mengawasi agar praktik pembuatan dodol berjalan lancar. Setelah pelatihan praktik pembuatan dodol, dilakukan pelatihan pengemasan dan pemasaran yang disampaikan oleh Tim secara informal dengan metode ceramah, diskusi, dan demonstrasi.

Kedua, dilakukan monitoring dan evaluasi (monev) pasca pelatihan dengan cara membandingkan pengemasan dan pemasaran sebelum dan setelah pelatihan. Evaluasi atas produk dodol dilakukan dengan metode pengamatan dan wawancara kepada pengusaha dodol sekaligus fasilitator pembuatan dodol, Ibu Maunah. Selain wawancara, monev juga dilakukan melalui metode kelompok diskusi terbatas (FGD) pada 26 Juli 2017 kepada beberapa perempuan peserta pelatihan, dua bulan setelah pelatihan.

\section{PEMBAHASAN}

\section{Praktik Pembuatan Dodol}

Mangrove pidada tumbuh dengan subur di Pantai Beting baik di pinggir pantai dan rumah-rumah penduduk. Akan tetapi, belum semua penduduk mengenal manfaat buah pidada, apalagi mengolahnya menjadi panganan yang bernilai 
ekonomis. Karena itu, pelatihan pembuatan dodol pidada secara tidak langsung juga berfungsi memberikan penyadaran atas manfaat buah mangrove pidada.

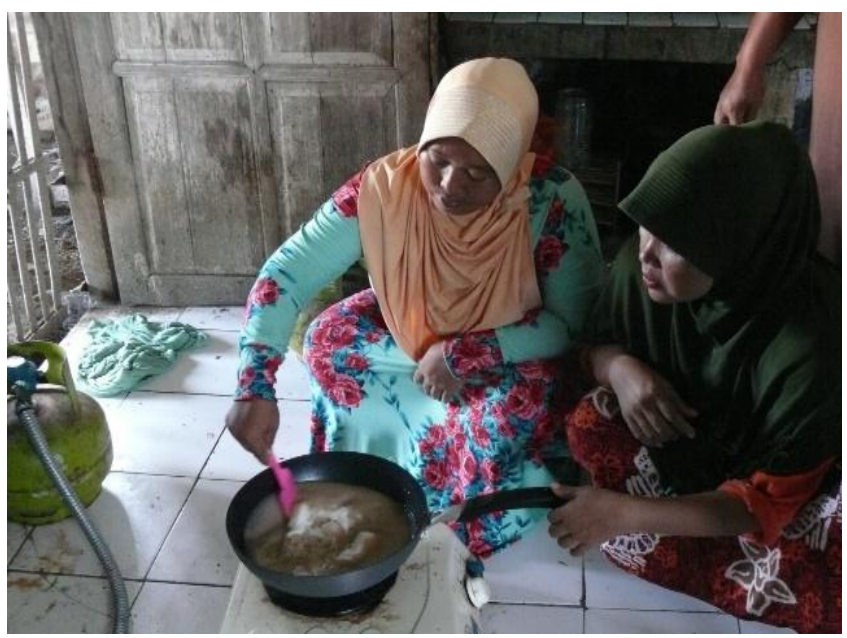

Gambar 3. Buah Pidada sedang Dimasak

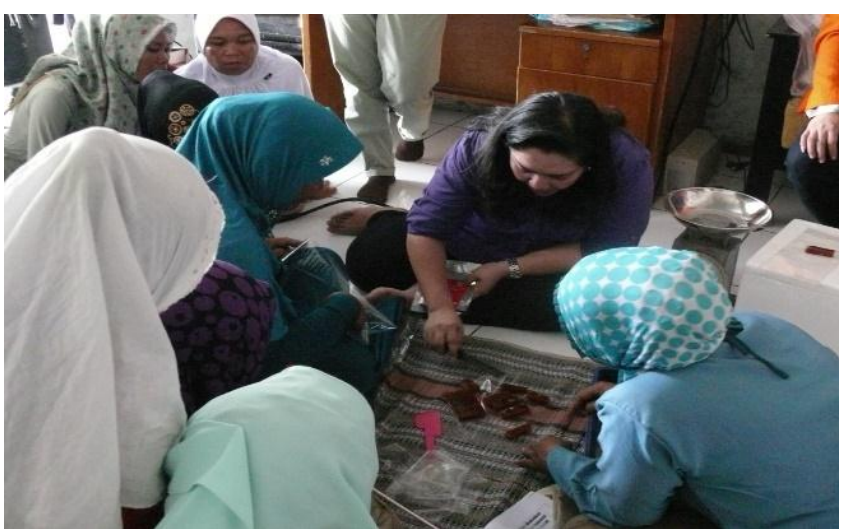

Gambar 4. Dodol Pidada Dipotong Sama Besar

Dengan bahan-bahan yang disiapkan Tim, peserta mengikuti langkah-langkah pembuatan dodol, dari pengupasan, pemasakan, hingga pemotongan. Pembuatan dodol hingga pendinginannya berlangsung tidak lebih dari tiga jam. Selanjutnya, dodol siap diiris dan dikemas. Para peserta mengamati demonstrasi pembuatan dodol, beberapa orang membantu memasaknya.

\section{Pelatihan Pengemasan dan Pemasaran}

Setelah dodol masak, peserta berkumpul untuk mengikuti penyampaian materi mengenai pengemasan (packaging) sebagai faktor yang menunjang penjualan. Ibarat "memilih calon istri, yang diamati pertama kali adalah kecantikannya". Begitu pula dalam mengemas dodol. Demikian analogi yang disampaikan oleh salah satu anggota Tim. Karena itu, diyakinkan kepada peserta bahwa tampilan kemasan dodol pidada perlu dipercantik agar mempunyai daya tarik untuk disentuh, dibaca apa yang tertera di dalam stiker, dan akhirnya dibeli.

Sebagai usaha rumahan, selama ini dodol pidada dijual dengan merk "Lintang Jaya". Dodol ini dibungkus mika ukuran $12 \mathrm{~cm} \times 8.5 \mathrm{~cm}$. dari segi rasa, Ibu Maunah mencoba mempertahankan rasa asam manis pidada agar tidak hilang jika diolah menjadi dodol. Dalam satu bungkus mika diisi dengan sepuluh dodol berbentuk lonjong (persegiempat) yang dijual dengan harga Rp5.000,00 per bungkus mika.

Dodol pidada "Lintang Jaya" setelah diiris-iris dimasukkan ke dalam plastik yang tipis. Hal itu dikomentari oleh Tim bahwasanya bungkus makanan sebaiknya menggunakan bungkus plastik yang tebal agar terkesan kuat dan eksklusif. Pembungkusannya harus rapat-rapat dan diikat dengan pengikat warna-warni sehingga unik, berbeda dengan dodol-dodol yang sudah banyak dijual. Dengan diikat rapat, dodol akan terbebas dari bakteri atau jamur yang mudah berkembang mengingat tingkat keasaman dodol tinggi sehingga jamur mudah menyerang. Disarankan juga agar bentuk dodol dibuat semenarik mungkin, tidak lagi persegipanjang seperti yang sudah banyak dijajakan orang. Dodol "Lintang Jaya" perlu membuat terobosan baru.

Selama ini bentuk dodol "Lintang Jaya" yang persegi empat itu tidak merata tebal tipisnya dan beratnya pun tidak diukur, hanya dihitung sejumlah sepuluh dodol untuk satu bungkus mika. Karena itu, dalam pelatihan ini disarankan agar setelah dodol dibungkus plastik, ditimbang seberat 100 gr lalu dibungkus dan dimasukkan ke dalam mika. Berat dodol sebaiknya dicantumkan di dalam label kemasan. Pembungkusan disarankan jangan sampai membuat isi plastik terlampau padat, tetapi agak dilonggarkan untuk memberi udara di dalam bungkus mika. Untuk peletakannya pun dodol diatur dalam posisi berdiri, bukan ditidurkan seperti yang selama ini dilakukan. Hal ini demi menjaga keutuhan bentuk dadu dari dodol agar tidak rusak.

Jika diamati secara saksama, kemasan mika dodol "Lintang Jaya" tidak ada bedanya dengan dodoldodol lainnya yang banyak dijual sebagai buah tangan. Karena itu, Tim memberi masukan agar produsen, dalam hal ini para perempuan di Pantai Beting, dapat mengubah strategi penjualan yang dapat menarik daya beli konsumen. 
Untuk lebih membuat konsumen tertarik pada produk dodol, kemasan mika diganti dengan standing pouch alumunium foil dan zipper warna gold yang lebih tebal. Selain itu, stiker diubah bukan lagi berbentuk kertas kwarto atau HVS yang ditempel di atas mika, melainkan didesain dengan stiker berwarna merah yang ditempel di atas mika. Selain lebih kuat dan tahan lama, stiker menambah kesan profesional.

Kemasan dalam foil memiliki keuntungan karena konsumen dapat melihat langsung bentuk produknya. Karena itu, perlu dijaga agar konsisten dalam ukuran dadu dodol pidada, berat isi yang tidak berbeda dengan berat yang tertulis dalam stiker, dan gambar serta warna stiker yang tetap.

Pengemasan yang memikat bertujuan untuk menggaet pasar. Karena dodol "Lintang Jaya" belum dikenal banyak orang, pemasaran dari mulut ke mulut, seperti yang saat ini dilakukan, dapat lebih efektif sebagai langkah awal. Strategi dengan penguatan relasi atau pertemanan ini perlu digiatkan lagi. Ditambah terobosan dengan menitipkan dodol di berbagai warung atau toko untuk lebih mempopulerkan produk dodol "Lintang Jaya".

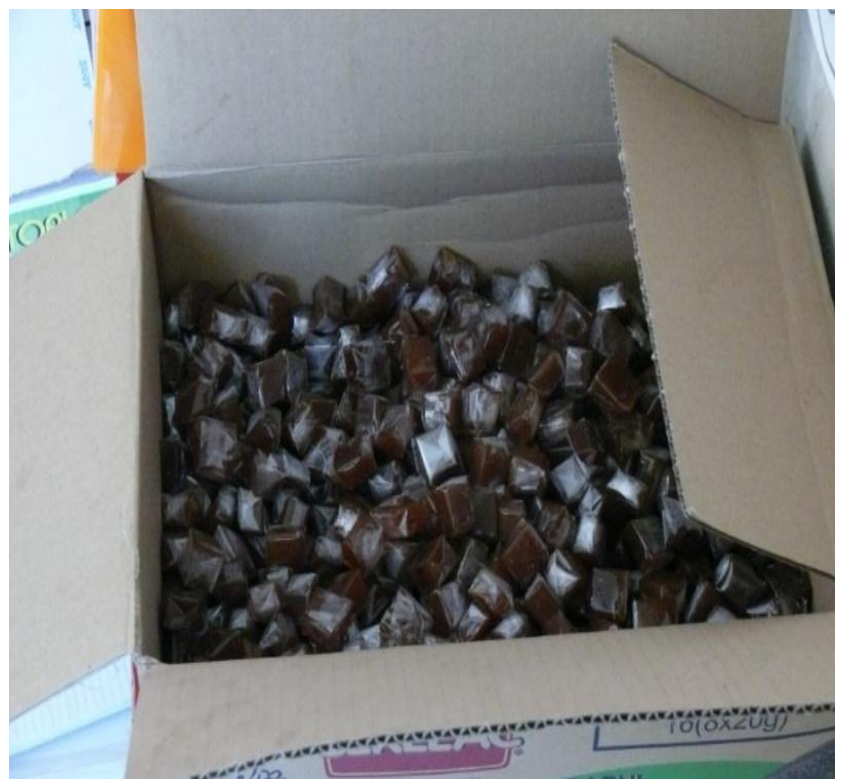

Gambar 5. Dodol Siap Dimasukkan ke dalam Kemasan

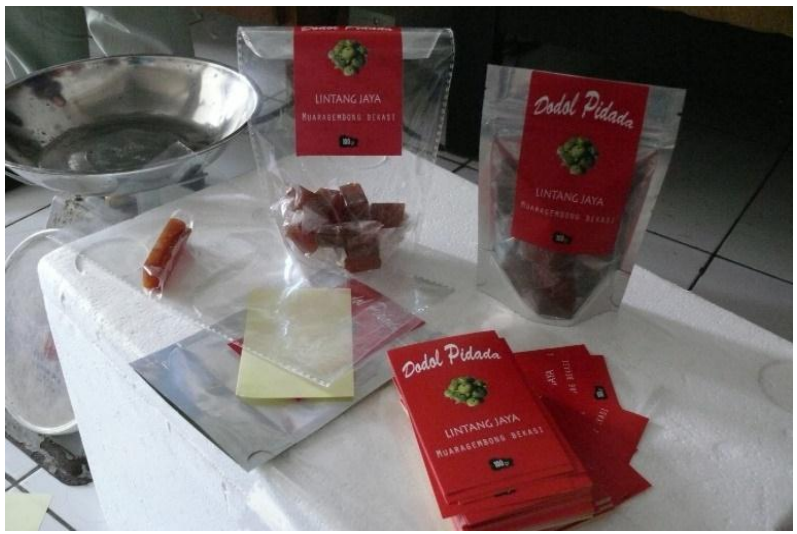

\section{Gambar 6. Dodol Pidada dalam Kemasan} Alumunium Foil

\section{Monitoring dan Evaluasi Pascapelatihan}

Evaluasi terhadap hasil pelatihan diadakan di kediaman lbu Maunah. Hadir pada pertemuan itu antara lain sepuluh perempuan yang membantu produksi dodol dan telah mengikuti pelatihan sebelumnya. Seusai pelatihan yang disampaikan oleh Tim, dodol dibuat secara bergotong royong. Para ibu memasak di dapur kediaman lbu Maunah dilakukan pada pagi hari setelah subuh agar tidak terlalu lama mendinginkan dodol. Membungkus juga dilakukan bersama-sama.

Mereka yang membantu pembuatan dodol diberi gaji oleh lbu Maunah sesuai dengan banyaknya kemampuan para ibu membungkus dodol. Biasanya setelah waktu dzuhur tiba, mereka selesai membungkus dan pulang ke rumah masing-masing. Semua peserta, termasuk lbu Maunah, membantu memasarkan kepada sanak saudara. Ibu Maunah yang bekerja sebagai guru PAUD lebih mempunyai waktu untuk berkeliling dan bertemu dengan banyak orang. la menjajakannya langsung ke berbagai tempat, seperti kecamatan, puskesmas, pengajian, arisan, sekolah. Bahkan, menitipkannya kepada kenalan untuk dibawa ke luar kota, seperti Tegal dan Batam. Lebih dari itu, Ibu Maunah beruntung bertemu dengan seseorang yang bersedia membeli dalam partai besar untuk dijual kembali secara daring hingga saat ini. Pemesanan meningkat khususnya pada bulan puasa menjelang lebaran, bulan Mei dan Juni 2017.

Di bawah ini adalah gambar dan hasil FGD dan wawacara tentang aspek bauran pemasaran (marketing mix), yaitu product, price, place, dan promotion. Keempatnya menjadi pembahasan di dalam tulisan ini mengingat keempatnya saling mendukung untuk keberhasilan pemasaran (Fuad, et al. 2000). 


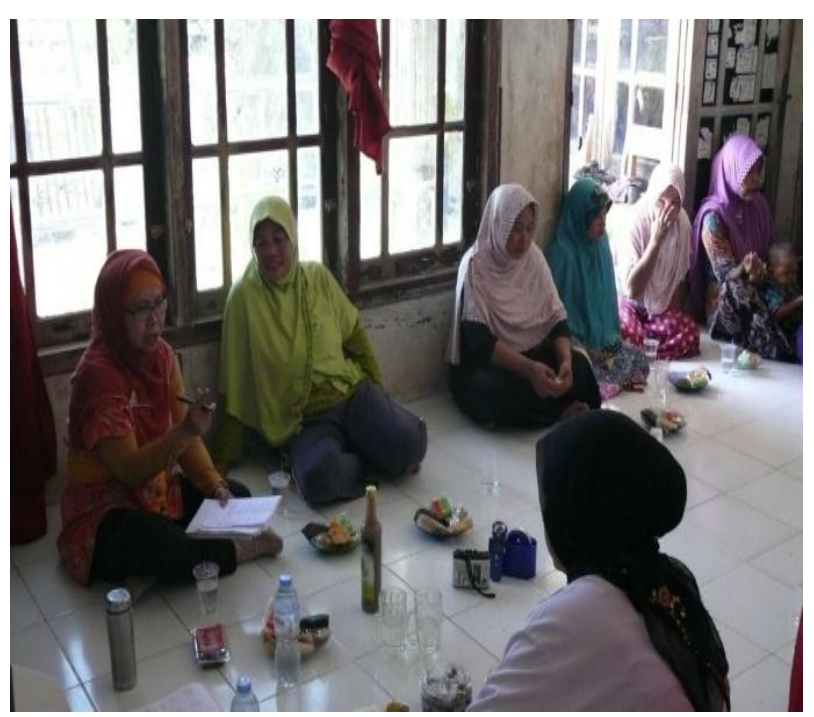

Gambar 7. Monev Pascapelatihan

\section{Produk}

Dodol pidada terbuat dari mangrove pidada. Menurut Ibu Maunah, dodol yang banyak dijual di lingkungan tempat tinggalnya umumnya terbuat dari ketan. Di lingkungan Pantai Beting memang belum banyak yang menjual dodol pidada. Kendatipun ada, menurut cerita Ibu Maunah, pembeli mengomentari rasa dodol pidada "Lintang Jaya" berbeda: rasa asam dan manisnya pas atau seimbang, sementara banyak dodol lainnya berasa asam. Selain itu, bentuk dodol pidada tidak buluk atau dekil seperti dodol-dodol pesaing. Dodol lainnya juga kadang-kadang ditemukan lengket di plastik pembungkusnya. Namun, dengan dihibahkannya satu panci teflon oleh Tim, dodol yang dimasak tidak lagi lengket.

Kekuatan produk ini adalah tidak menggunakan pewarna dan pengawet buatan. Kandungan vitamin A, B, dan C yang terkandung di dalam buah merupakan nilai jual yang diyakini banyak dicari orang. Kemasan alumuniumfoil yang disarankan Tim diharapkan dapat digunakan sebagai daya tarik. Akan tetapi, karena harganya cukup mahal, kemasan dodol masih menggunakan mika dan toples. Menurut peserta monev, kemasan menjadi perhatian utama jika dodol akan dipasarkan ke luar Bekasi, seperti Jakarta, karena mereka meyakini orang kota suka dengan kemasan yang bagus, sedangkan orang-orang di kampung cukup dengan mengandalkan rasa, tidak memikirkan kemasan.

\section{Harga}

Adanya perubahan kemasan berimplikasi pada penyesuaian harga dodol yang semula Rp5.000,00 menjadi Rp6.000,00 untuk isi 100 gr. Kemajuan lain yang ditunjukkan adalah dodol tidak hanya dikemas dengan mika, tetapi juga dengan toples yang berisi $400 \mathrm{gr}$ dan dijual seharga Rp25.000,00. Dodol pidada dalam kemasan plastik dijual Rp 10.000,00 (isi $200 \mathrm{gr}$ ). Sejak bulan Ramadhan (Mei 2017) dodol dijual via daring. Harga dodol pidada yang dijual Rp6.000,00, via daring oleh perantara dijual Rp $10.000,00$. Adapun dodol dalam toples jika dijual via daring menjadi Rp30.000,00 dari harga normal Rp25.000,00. Pada masa mendatang, direncanakan dodol akan dijual dalam satu bungkus dadu seharga Rp500,00 untuk konsumsi anak-anak. Agar menarik, dodol direncanakan akan dicetak bergambar Mickey Mouse, kupukupu, bebek, atau apa pun agar menarik bagi anak-anak.

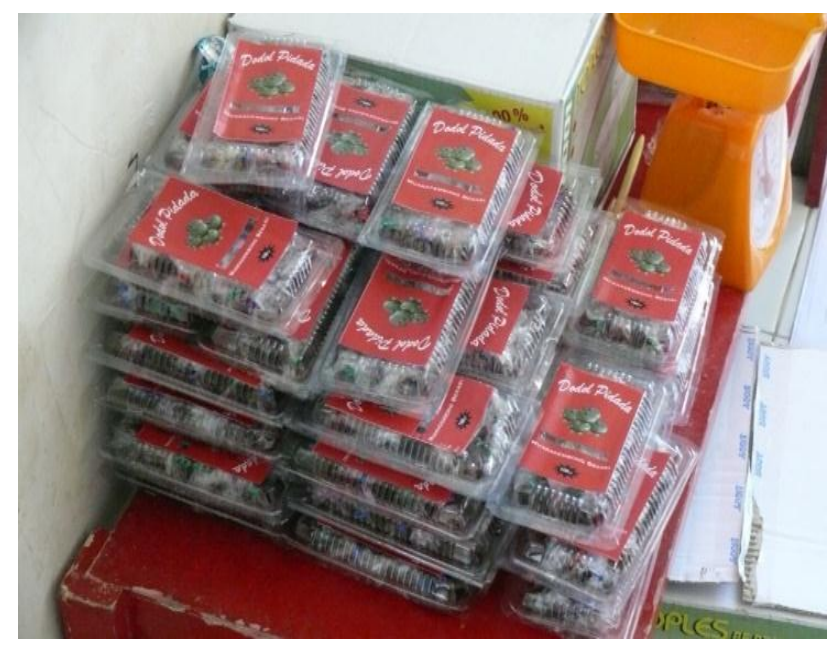

Gambar 8. Dodol Pidada Siap Dipasarkan

\section{Tempat}

Selain Ibu Maunah, sudah terdapat warung penjual dodol pidada di depan rumahnya. Namun, ibu Maunah tidak menirunya, ia tidak membuka warung untuk penjualan dodolnya. Pemasaran dodol ke luar daerah dibantu oleh suaminya. Secara langsung Ibu Maunah juga menawarkannya kepada orang-orang ketika berada di tempattempat tertentu, seperti sekolah dan kecamatan. Perempuan lainnya membantu lbu Maunah mempromosikan kepada kerabat atau sanak saudara dengan cara memberikan dodol sebagai oleh-oleh dengan harapan ada pesanan di kemudian hari. 


\section{Promosi}

Kaum perempuan penghasil dodol "Lintang Jaya" selalu mempromosikan dodolnya berkhasiat karena pidada antara lain mengandung vitamin C yang dapat mencegah sariawan dan melangsingkan tubuh. Selain itu, tidak ada bahan pengawet di dalamnya. Sayangnya, kandungan dan manfaatnya ini belum diekspos di dalam label kemasan, padahal semua itu dapat menjadi daya tarik pembeli mengingat saat ini masyarakat cukup peduli terhadap kesehatan.

Banyak cara untuk mempromosikan produk. Namun, strategi pemasaran yang paling cepat memberi pengaruh kepada konsumen dengan mengubah perilaku dan sikap mereka adalah komunikasi dari mulut ke mulut (word of mouth/WOM) (Brown \& Reingen, 1987 dalam Tsai et al., 2014). Strategi pemasaran ini paling berpengaruh dalam pembelian produk makanan (Katz \& Lazarsfeld, 1955 dalam Tsai et al., 2014). Karena itu, untuk menyebarluaskan produk baru dodol pidada ini, diawali dengan pemasaran dari mulut ke mulut. Strategi inilah yang sudah lebih dahulu dilakukan oleh para peserta pelatihan di Pantai Beting.

Tabel 1. Perbandingan Produksi Dodol Pidada Sebelum dan Sesudah Pelatihan

\begin{tabular}{|c|c|c|}
\hline Penilaian & Sebelum & Setelah \\
\hline Kebersihan & $\begin{array}{l}\text { Kurang } \\
\text { diperhatikan }\end{array}$ & Diperhatikan \\
\hline Produksi & 5 kg per minggu & 10 kg per hari \\
\hline Kemasan & $\begin{array}{ll}\text { Mika, } & \\
\text { dodol } & \text { dilipat } \\
\text { dengan } & \text { plastik } \\
\text { yang tipis } & \end{array}$ & $\begin{array}{l}\text { Mika, toples, } \\
\text { alumunium foil, } \\
\text { dodol } \\
\text { dibungkus } \\
\text { dalam plastik } \\
\text { tebal dan diikat } \\
\text { dengan ikatan } \\
\text { plastik } \\
\text { berwarna-warni. }\end{array}$ \\
\hline Label & $\begin{array}{l}\text { Cetakan di atas } \\
\text { kertas putih } \\
\text { dengan teks } \\
\text { berwarna hitam. }\end{array}$ & Stiker full color \\
\hline Bentuk dodol & $\begin{array}{l}\text { Persegiempat, } \\
\text { panjang seruas } \\
\text { jari tengah, } \\
\text { sudah seragam }\end{array}$ & $\begin{array}{l}\text { Bulat, dadu, } \\
\text { belum seragam }\end{array}$ \\
\hline Merek & Lintang Jaya & Salmah \\
\hline Pasar & $\begin{array}{l}\text { Mulut ke mulut, } \\
\text { titip di warung/ } \\
\text { toko }\end{array}$ & $\begin{array}{l}\text { Mulut ke mulut, } \\
\text { titip di } \\
\text { warung/toko, } \\
\text { daring }\end{array}$ \\
\hline
\end{tabular}

Dodol dijual selain dari mulut ke mulut juga dititipkan di warung-warung, dipromosikan kepada tetamu, dijajakan langsung ke beberapa tempat publik. Merek dodol dalam kemasan toples diberi stiker bukan lagi menggunakan label "Lintang Jaya", melainkan "Salmah" yang merupakan representasi dari nama anak dari produsen dodol pidada, yaitu Ibu Maunah. Bahkan, dikemudian hari menurut lbu Maunah, ia akan mencari nama yang paling menjual, bila perlu nama Salmah diganti menjadi The Maunah atau Mak Unah. Dari hasil FGD dengan perempuan peserta pelatihan di Pantai Beting, dipaparkan perbandingan produksi sebelum dan setelah diberikan pelatihan seperti pada tabel 1.

\section{KESIMPULAN}

Hasil penjualan dan produksi pasca pelatihan sudah menunjukkan peningkatan. Sistem pembayaran insentif dan bonus pengerjaan dodol sudah didesain atas kesepakatan bersama. Hal ini menunjukkan sumber daya manusia sudah mulai diberdayakan dan sudah terbina jiwa kewirausahaan. Kegiatan ini menghasilkan produk dodol yang berbeda dari sebelumnya. Perbedaan meliputi tingkat kebersihan, bentuk dodol, dan kemasannya. Harga dodol telah mengalami penyesuaian. Adapun produksi masih dilakukan di rumah sendiri, dan pemasaran masih dilakukan sendiri oleh produsen atau melalui kenalan pemilik warung atau toko. Promosi bukan hanya dari mulut ke mulut, melainkan sudah sampai ke pemasaran secara daring meskipun masih menggunakan perantara. Pengolahan mangrove pidada menjadi dodol oleh kaum perempuan di Pantai Bahagia diharapkan dapat berjalan secara berkelanjutan. Dengan merasakan manfaat ekonomi, diharapkan kaum perempuan di Pantai Beting dapat termotivasi untuk turut melestarikan dan memanfaatkan mangrove di lingkungan mereka. Sambil terus mencari pelanggan, memperluas jejaring, pemasaran oleh para perempuan perlu dicarikan alternatif distribusi pemasaran yang lebih luas jangkauannya, misalnya diikutsertakan dalam pameran, dilombakan agar mendapatkan pembelajaran dari produk sejenis, atau dijual secara daring.

\section{DAFTAR PUSTAKA}

Fuad, M, et al., 2000, Pengantar Bisnis, Jakarta: Gramdia Pustaka Utama.

Hamid, N. dan Martini, S., 2013, Pengaruh Faktor Sosial Ekonomi terhadap Partisipasi Masyarakat dalam Pelestarian Mangrove di kelurahan Wonorejo Kecamatan Rungkut Kota Surabaya. Swara Bhumi, 2 (1): 48-55.

Ifthianty,T.I.T. et al., 2014, Economic Valuation of Mangrove Resource in Baros Coasta Tirtohargo Village Sub-District of Kretek, Kawistara, 4 (2): 111-149. 
Manalu, et al., 2013, Kandungan Zat Gizi Makro dan Vitamin Produk Buah Pedada (Sonneratia caseolaris), Jurnal Penelitian Gizi dan Makanan, 36 (2).

Noor,Y.R., 2006, Panduan pengenalan mangrove di Indonesia. Saduran dari Giesen et al. A Field Guide of Indonesia Mangrove. Bogor: Ditjen PHKA.

Peran perempuan membrantas kemiskinan. Kompas, 23 Januari 2017.

Purnobasuki, H., 2004, Potensi mangrove sebagai tanaman obat. Biota, IX (1): 125-126.

Sabana,C., (Maret 2014), Kajian pengembangan produk makanan olahan mangrove. Jurnal Ekonomi dan Bisnis, 14 (1): 40-46.

Tsai, G.Y, Kuo, T, Liu, Y.C, Lu, Iuan-Yuan, 2014. Study of Consumer Attitude toward Online Shopping of Seafood. Proceeding $12^{\text {th }}$ ANQ Conggress in Singapore, $1-11$.

Wiediartini, Santiasih, I, dan Riantini, R., 2016, Strategi Pemasaran Sirup Mangrove. Seminar Nasional Maritim, Sains, dan Taeknologi Terapan Polikteknik Perkapalan Negeri Surabaya, 01: 1-4.

Wiyono M. 2009. Pengelolaan Hutan Mangrove dan Daya Tariknya sebagai Objek Wisata di Kota Probolinggo. Jurnal Aplikasi Manajemen, 7 (2): 411-419. 